\title{
Downregulation of HNF1 homeobox $B$ is associated with drug resistance in ovarian cancer
}

\author{
JIANCHAO LI ${ }^{1,2}$, YONGHONG ZHANG ${ }^{2}$, YUTAO GAO $^{3}$, YUQIAN CUI $^{4}$, HUA LIU $^{5}$, MI LI $^{6}$ and YONGJIE TIAN ${ }^{1}$ \\ ${ }^{1}$ Department of Obstetrics and Gynecology, Provincial Hospital Affiliated to Shandong University, Jinan, Shandong; \\ ${ }^{2}$ Department of Obstetrics and Gynecology, Muping Traditional Chinese Medicine Hospital, Yantai, Shandong; \\ ${ }^{3}$ Department of Obstetrics and Gynecology, Beijing Chao-Yang Hospital, Affiliated to Capital Medical University, Beijing; \\ ${ }^{4}$ Center for Reproductive Medicine, Provincial Hospital Affiliated to Shandong University, Jinan, Shandong; \\ ${ }^{5}$ Department of Obstetrics and Gynecology, Affiliated Hospital of Weifang Medical University, Weifang, Shandong; \\ ${ }^{6}$ Department of Nursing, Shandong College of Traditional Chinese Medicine, Yantai, Shandong, P.R. China
}

Received March 15, 2014; Accepted May 29, 2014

DOI: $10.3892 /$ or.2014.3297

\begin{abstract}
The expression of HNF1 homeobox B (HNF1B) is associated with cancer risk in several tumors, including ovarian cancer, and its decreased expression play roles in cancer development. However, the study of HNF1B and cancer is limited, and its association with drug resistance in cancer has never been reported. On the basis of array data retrieved from Oncomine and Gene Expression Omnibus (GEO) online database, we found that the mRNA expression of HNF1B in 586 ovarian serous cystadenocarcinomas and in platinum-resistant A2780 epithelial ovarian cancer cells was significantly decreased, indicating a potential role of HNF1B in drug resistance in ovarian cancer. Based on this finding, comprehensive bioinformatics analyses, including protein/ gene interaction, protein-small molecule/chemical interaction, biological process annotation, gene co-occurrence and pathway enrichment analysis and microRNA-mRNA interaction, were performed to illustrate the association of HNF1B with drug resistance in ovarian cancer. We found that among the proteins/ genes, small molecules/chemicals and microRNAs which directly interacted with $\mathrm{HNF} 1 \mathrm{~B}$, the majority was associated with drug resistance in cancer, particularly in ovarian cancer. Biological process annotation revealed that HNF1B closely related to 24 biological processes which were all notably associated with ovarian cancer and drug resistance. These results indicated that the downregulation of HNF1B may contribute to drug resistance in ovarian cancer, via its direct interactions with these drug resistance-related proteins/genes, small molecules/chemicals and microRNAs, and via its regulations on the
\end{abstract}

Correspondence to: Professor Yongjie Tian, Department of Obstetrics and Gynecology, Provincial Hospital Affiliated to Shandong University, 324 Jingwu Road, Jinan, Shandong 250021, P.R. China E-mail: tianyongjie@sdu.edu.cn

Key words: HNF1 homeobox B, drug resistance, ovarian cancer, bioinformatics drug resistance-related biological processes. Pathway enrichment analysis of 36 genes which co-occurred with HNF1B, ovarian cancer and drug resistance indicated that the HNF1B may perform its drug resistance-related functions through 4 pathways including ErbB signaling, focal adhesion, apoptosis and p53 signaling. Collectively, in this study, we illustrated for the first time that HNF1B may contribute to drug resistance in ovarian cancer, potentially through the 4 pathways. The present study may pave the way for further investigation of the drug resistance-related functions of HNF1B in ovarian cancer.

\section{Introduction}

Ovarian cancer is the most lethal cancer of the female reproductive system, with a high rate of mortality worldwide. Approximately $70 \%$ of ovarian cancers are diagnosed at advanced stage and only $40 \%$ of women with such cancers can expect to survive 5 years (1). The current therapy for ovarian cancer is debulking surgery followed by cisplatin-centered chemotherapy (2). Although cisplatin-centered chemotherapy, which is the currently preferred treatment modality in human ovarian cancer, can achieve a complete response rate of $40-60 \%$ in advanced ovarian cancer patients, the main obstacle to a successful treatment for ovarian cancer is the development of drug resistance to combined chemotherapy, and that finally leads to mortality (3-5).

Drug resistance, including intrinsic and acquired resistance, generally develops after the treatments to advanced stage cancer patients with chemotherapies, and results from a variety of factors including individual variations in patients and somatic cell genetic differences in tumors $(5,6)$. Several molecular mechanisms implicated in the rise of resistance in cellular models of ovarian cancer include decreased cellassociated drugs, altered drug inactivation, increased DNA damage tolerance/repair, increased anti-apoptotic regulator activity and growth factor receptor deregulation $(4,7)$. In addition, apoptosis, which is associated with the expression of specific 'death' genes and downregulation of 'survival' counterparts, is crucial in determining the response to chemotherapeutic agents $(8,9)$. However, regardless of the 
mechanisms, abnormal expression of drug resistance-related genes often plays important roles in drug resistance (10).

HNF1 homeobox B (HNF1B), a transcription factor (11-13), is identified as a transforming oncogene required for the survival of cancer cells (14). However, another study indicated that HNF1B may function as a tumor suppressor gene in chromophobe renal cell carcinogenesis through control of PKHD1 expression (15). It has been proven that HNF1B is downregulated in ovarian, gastric, pancreatic and colorectal cells $(16,17)$, and its suppression influences cellular phenotypes associated with tumor-related properties in prostate cancer cells (18). The associations of HNF1B with cancer focus mainly on the single nucleotide polymorphisms (SNPs). Gudmundsson et al (19) first reported the association of HNF1B variant with prostate cancer risk. Later, the two SNPs (rs4430796 and rs11649743) in HNF1B associated with prostate cancer risk were identified $(20,21)$. Further study indicated that the rs4430796 is also associated with endometrial cancer risk in women of European background (22). Similarly, rs7501939 in HNF1B is associated with the risk of prostate cancer (22) and endometrial cancer (22). In ovarian cancer, HNF1B is identified as a subtype-specific susceptibility gene (24-26). The different SNPs associate with invasive serous (rs7405776) and clear cell (rs11651755) epithelial ovarian cancer, and the risk alleles for the serous subtype associate with HNF1B high methylation and downregulation, and unmethylated and expressed HNF1B is presented in clear cell tumors (24).

Collectively, the expression of HNF1B is associated with cancer risk in several tumors, and its decreased expression play roles in cancer development. However, studies of HNF1B with ovarian cancer are limited, and its association with drug resistance in cancer has yet to be reported. In the present study, we demonstrated that the expression of HNF1B was significantly decreased in serous cystadenocarcinomas and platinum-resistant A2780 ovarian cancer cells, according to the microarray data retrieved from the Oncomine and Gene Expression Omnibus (GEO) online database, respectively, and it indicated that HNF1B may be involved in the drug resistance in ovarian cancer. Following this premise, the present study illustrated that the downregulation of HNF1B may contribute to drug resistance in ovarian cancer, based on our comprehensive bioinformatics analyses.

\section{Methods and database}

The microarray data of HNF1B in ovarian cancer tissues was retrieved from the Oncomine online database (https://www. oncomine.org/resource/main.html) $(27,28)$. The microarray data of HNF1B in ovarian cancer cells was retrieved from the GEO (http://www.ncbi.nlm.nih.gov/geoprofiles/) $(28,29)$. The protein/gene-protein/gene interaction analysis was performed using GeneMANIA online tool (http://www.genemania.org/) (30-32). Protein-small molecule/chemical interaction analysis was performed using STITCH 4.0 beta (http://stitch-beta. embl.de/) (33-35) and BiologicalNetworks2 (http://biologicalnetworks.org/) (36,37). Annotation of biological process and gene co-occurrence analysis were performed using Coremine Medical online database (http://www.coremine.com/medical/) (38). The pathway enrichment analysis was performed using the DAVID online tool (http://david.abcc.ncifcrf.gov/)
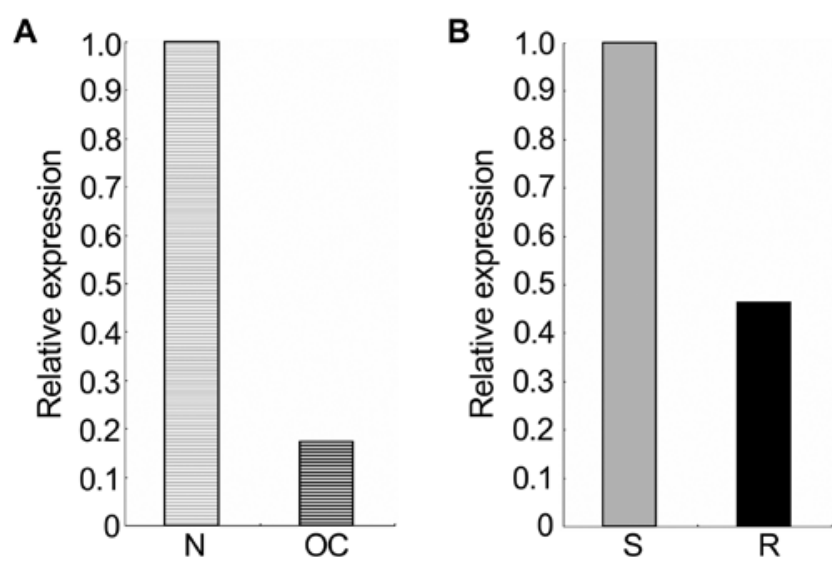

Figure 1. mRNA expression of HNF1B in ovarian cancer tissues and drugresistant cells. (A) Based on the TCGA ovarian array data retrieved from the Oncomine online database, the mRNA expression of HNF1B in 586 ovarian serous cystadenocarcinomas was significantly decreased compared with the expression in 8 ovaries used as normal controls $(\mathrm{p}=7.06 \mathrm{E}-6$; fold-change=-5.776). The expression of HNF1B in the Oncomine database is presented as fold-changes (ovarian cancer vs. normal). In the present study, the expression of HNF1B in the normal control was normalized to 1.0, and all data are presented as relative expression. (B) Based on the array data retrieved from GEO profiles (GDS3754), the mRNA expression of HNF1B in platinum-resistant A2780 epithelial ovarian cancer cells was notably decreased compared with the expression in their sensitive counterpart (with 5 replicates each; fold-change $=-2.16$ ). The expression data in the GEO Profiles database is presented as expression values. In the present study, the expression of HNF1B in sensitive cancer cells was normalized to 1.0 , and all data are presented as relative expression.

$(39,40)$. The microRNAs targeted to the gene were predicted by miRWalk online tool which included 10 prediction tools (DIANAmT, miRanda, miRDB, miRWalk, RNAhybrid, PICTAR4, PICTAR5, PITA, RNA22 and Targetscan) (http:// www.umm.uniheidelberg.de/apps/zmf/mirwalk/) (41).

\section{Results}

mRNA expression of HNFIB is notably decreased in ovarian cancer tissues and in platinum-resistant cells. The mRNA expression data of HNF1B in ovarian cancers and in platinumresistant A2780 ovarian cancer cells was retrieved from the Oncomine and GEO profile online database, respectively. As shown in Fig. 1, the mRNA expression of HNF1B in 586 ovarian serous cystadenocarcinomas was significantly decreased compared with the expression in 8 ovaries used as normal controls ( $\mathrm{p}=7.06 \mathrm{E}-6$; fold-change $=-5.776$ ), and its expression in platinum-resistant A2780 epithelial ovarian cancer cells was notably decreased compared with the expression in their sensitive counterpart (with 5 replicates each; fold-change $=-2.16$ ). These results indicated that the decreased expression of HNF1B may be involved in the development of ovarian serous cystadenocarcinomas and drug resistance.

Protein/gene interaction analysis indicating the association of HNF1B with drug resistance in ovarian cancer. The protein/gene interaction of HNF1B with other proteins/genes was analyzed using the GeneMANIA online database. As shown in Fig. 2, HNF1B has direct interactions with 10 proteins/genes; among these, HNF1B shared protein domain, 


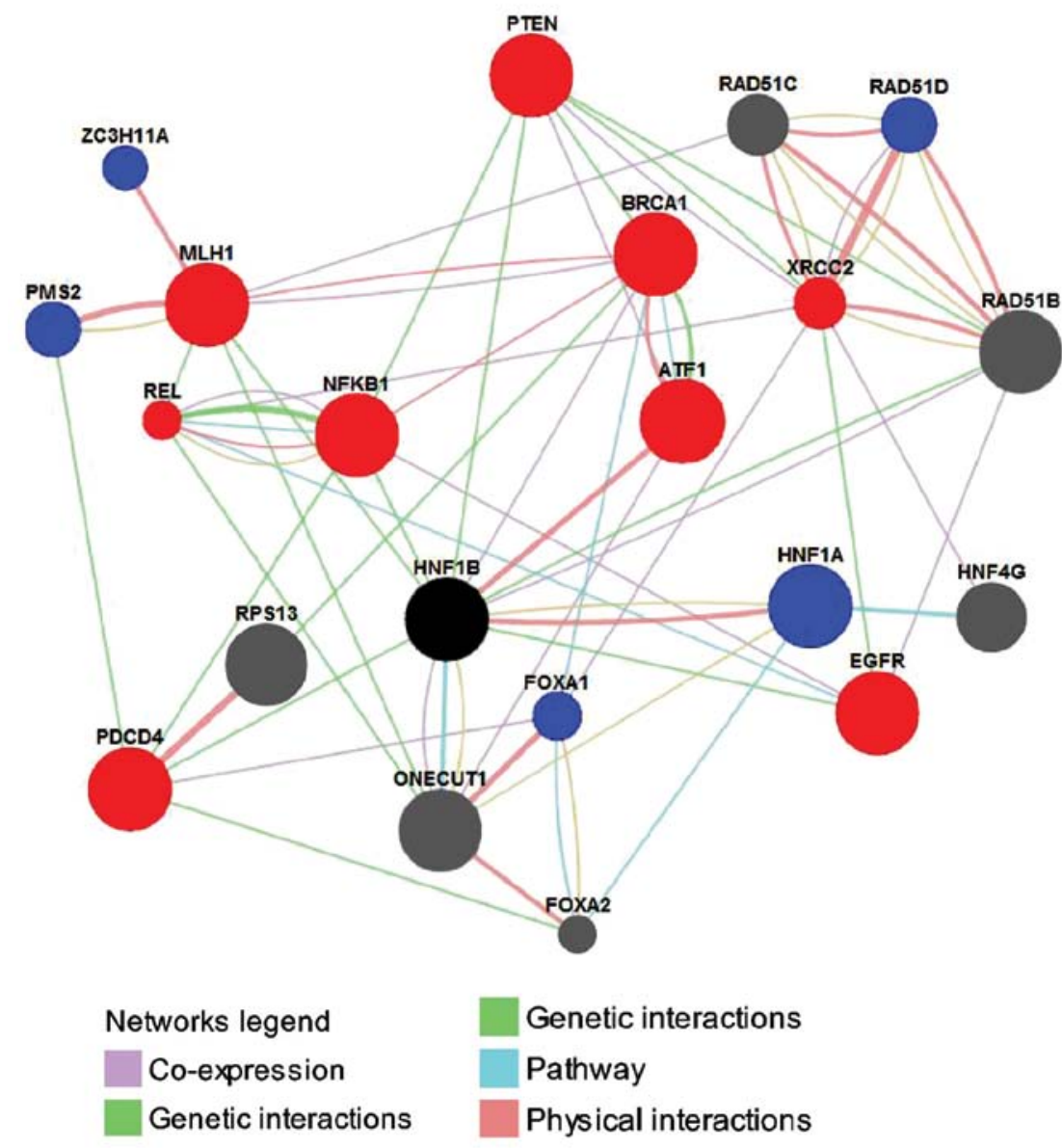

Figure 2. Protein/gene-protein/gene interaction network of HNF1B generated using the GeneMANIA online tool. The query in black was the target HNF1B, the queries in red were the proteins/genes associated with drug resistance in ovarian cancer, and the queries in blue were the proteins/genes associated with drug resistance in other cancers. The types of interactions between proteins/genes are illustrated as indicated by the network legend.

shared pathways and co-expressed with ONECUT1, had genetic interactions with NFKB1, PTEN, EGFR, PDCD4 and MLH1, had genetic interactions and co-expressed with RAD51B, had physical interactions and shared the pathway with HNF1A, had physical interactions with ATF1 and co-expressed with BRCA1. With the exception of the RAD51B and ONECUT1, the other 8 proteins/genes have all been proven to be closely associated with drug resistance in ovarian cancer. For example, BRCA1 is a well-known TSG and its downregulation contributes to the enhancement of drug resistance in ovarian cancer $(42,43)$. PTEN also is a TSG, and its downregulation results in the development of drug resistance in OVCAR-3 cells and the alterations conferred resistance to cisplatin through the activation of PI3K/Akt and the inhibition of Bax translocation (44). Further research indicated that overexpression of PTEN reverses chemoresistance to cisplatin in human ovarian cancer cells through inactivation of the PI3K/AKT cell survival pathway and may serve as a potential molecular target for the treatment of chemoresistant ovarian cancer (45). NFKB1 functions as a biphasic regulator, either suppressing or enhancing the development of ovarian cancer. As a tumor suppressor in ovarian cancer cell lines, NFKB1 regulates MAPK, while in the aggressive chemoresistant isogenic variants of these lines it plays a role in apoptosis (46). In addition, PDCD4 enhances chemosensitivity of ovarian cancer cells by activating death receptor pathway in vitro and in vivo (47), and the loss of MLH1 mediated by methylation can lead to the cisplatin-resistance in ovarian cancer $(48,49)$. In addition, EGFR $(50,51), \operatorname{ATF} 1(52,53)$ and HNF1A $(55)$ are all associated with drug resistance in ovarian and other types of cancer.

In addition to the direct interactions, there were another 10 proteins/genes in network which indirectly interacted with HNF1B; among those, 6 proteins/genes including REL $(55,56)$, CRCC2 (57), PMS2 (58), ZC3H11A (10), FOXA1 (59) and RAD51D (60) have been proven to be associated with drug resistance in ovarian and other cancers. For example, REL contributes directly to elevated uPA gene expression in human ovarian cancer cells (55), thereby promoting the multiple functions of uPA during tumor growth and metastasis, including drug resistance (56). Similarly, a naturally occurring genetic variant of human XRCC2 confers increased resistance to cisplatin-induced DNA damage in ovarian cancer (57).

Collectively, among the total 20 proteins/genes that interacted with HNF1B, 14 were associated with drug resistance in cancers, of which 9 were associated with drug resistance in ovarian cancer. Thus, given the strong interactions of HNF1B with those proteins/genes, we concluded that HNF1B may be involved in the drug resistance in cancer, particularly in ovarian cancer. 
$\mathbf{A}$

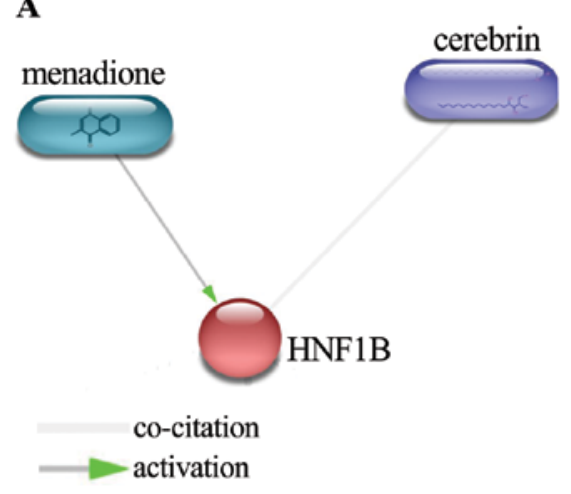

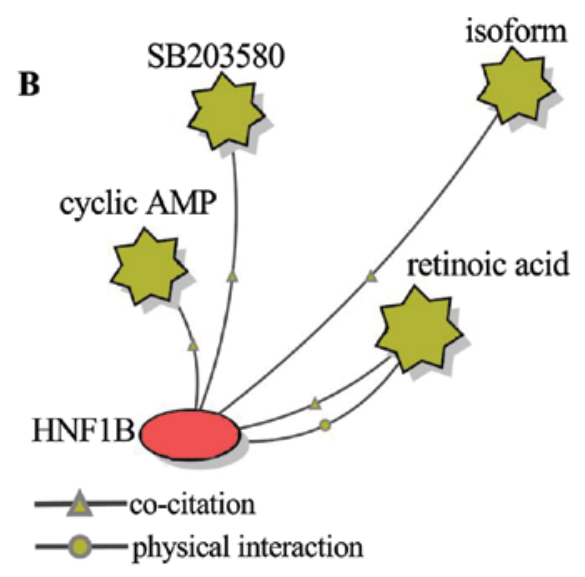

Figure 3. Protein-small molecule/chemical interaction analysis of HNF1B with chemicals by (A) STITCH 4.0 beta and (B) BiologicalNetworks2. The types of interaction between HNF1B and chemicals are shown.

Protein-small molecule/chemical interaction analysis indicating the association of HNF1B with drug resistance in ovarian cancer. Protein-small molecule/chemical interaction analysis was performed using STITCH 4.0 beta and BiologicalNetworks2 to further elucidate the associations of HNF1B with drug resistance in ovarian cancer. A total of 6 small molecules/chemicals were identified to interact with HNF1B. Among these, 4 chemicals, including menadione, SB203580, retinoic acid and cyclic AMP, have been proven to be closely related to drug resistance in ovarian cancer. Menadione is identified as a substrate of P-gp, which, presumably, acts as the mechanism for the chemosensitizing effect (61). The treatment of ovarian cancer cells with ascorbate:menadione resulted in the degradation of nuclear and DNA, which finally led to the cell death $(62,63)$. Thus, menadione is considered to be a promising chemotherapeutic enhancer by its ability to circumvent drug resistance, in addition to its own anticancer activity (61). Menadione activated HNF1B according to protein-chemical interaction (Fig. 3A), suggesting that the expression of HNF1B sensitizes the cancer cells to the anticancer drug; this, in turn, indicated that the decreased expression of HNF1B would contribute to drug resistance. Furthermore, HNF1B had physical interaction and co-citation with retinoic acid. Retinoic acid is identified as a suppressor of ovarian carcinoma cell growth (64); it sensitizes cancer cells to paclitaxel in part through survivin downregulation and the promotion of aberrant mitotic progression results in apoptosis (65). Retinoic acid also potentiates the chemotherapeutic effect of cisplatin by inducing differentiation of tumor initiating cells (66). In addition, HNF1B interacts with SB203580 and cyclic AMP. SB203580 is an inhibitor of p38MAPK, which is related to paclitaxel resistance of ovarian carcinoma, and blockade of the p38MAPK pathway can promote the apoptosis of the drug-resistant cells and reverse the drug resistance (67). The cyclic AMP can reduce the induction of AP-1 binding, which is required for the activation of IL8 by paclitaxel (68). The presence of IL8 in paclitaxel-treated ovarian cancer cells contributed to the development of paclitaxel resistance (69). These results indicated that the cyclic AMP is also involved in the development of drug resistance in ovarian cancer. Collectively, of the 6 small molecules/chemicals that inter-

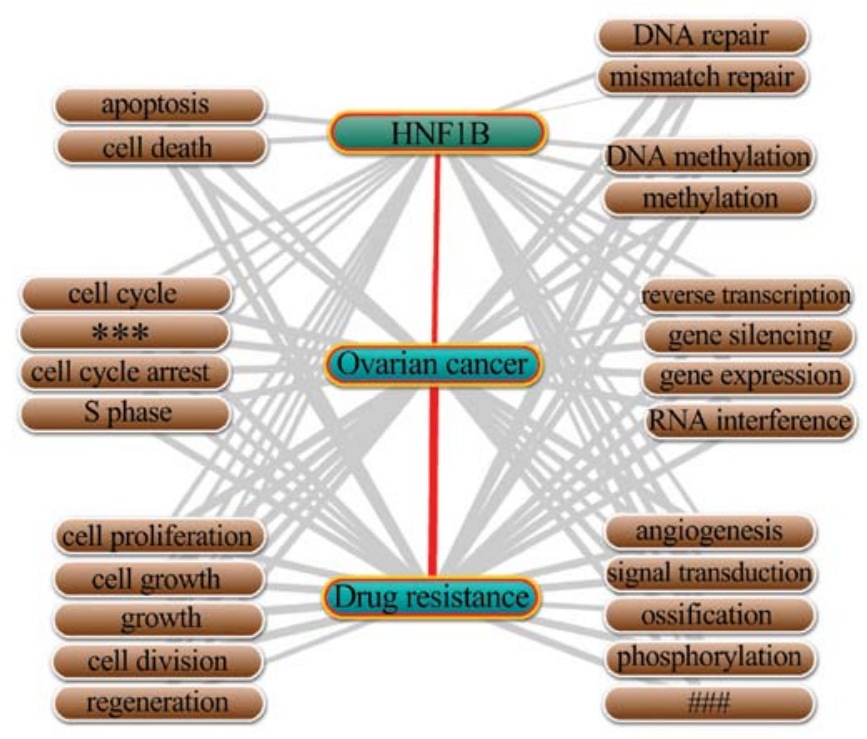

Figure 4. Annotation of the biological processes of HNF1B with ovarian cancer and drug resistance using the Coremine Medical online database/tool. The top 24 biological processes $(\mathrm{p}<0.01)$ which closely related to the three terms were annotated. ${ }^{* * *}$ Regulation of cell cycle; ${ }^{\# \#}$ epithelial to mesenchymal transition.

acted with HNF1B, 4 were associated with drug resistance in ovarian cancer, suggesting that HNF1B may contribute to the development of drug resistance in ovarian cancer.

Biological process annotation indicating the association of $H N F 1 B$ with drug resistance in ovarian cancer. The biological process annotation was performed using Coremine Medical online database/tool. As shown in Fig. 4, a total of 24 biological processes were annotated with HNF1B, ovarian cancer and drug resistance $(\mathrm{p}<0.01)$. Given the close relationships of HNF1B with the 24 processes, and the close relationships of the 24 processes with ovarian cancer and drug resistance, we concluded that HNF1B may contribute to the drug resistance in ovarian cancer via its effects on these biological processes. The 24 biological processes which annotated with HNF1B, 
Table I. Pathway enrichment analysis of the 36 genes which co-occurred with HNF1B, drug resistance and ovarian cancer, in accordance with Coremine Medical.

\begin{tabular}{lccc}
\hline KEGG pathway & $\begin{array}{c}\text { P-value } \\
(<0.01)\end{array}$ & $\begin{array}{c}\text { Benjamini } \\
(<0.01)\end{array}$ & \multicolumn{1}{c}{$\begin{array}{c}\text { The genes co-occurring with HNF1B, drug resistance } \\
\text { and ovarian cancer }\end{array}$} \\
\hline $\begin{array}{l}\text { ErbB signaling pathway } \\
\text { Focal adhesion }\end{array}$ & $3.2 \mathrm{E}-8$ & $2.8 \mathrm{E}-7$ & CDKN1A, EGFR, JUN, PIK3CA, AKT1, ERBB2, ERBB3, MYC \\
$\begin{array}{l}\text { Apoptosis } \\
\text { p53 signaling pathway }\end{array}$ & $2.8 \mathrm{E}-7$ & $3.9 \mathrm{E}-6$ & BCL2, COL11A2, CCND1, EGFR, JUN, PTEN, PIK3CA, AKT1, ERBB2 \\
& $1.5 \mathrm{E}-4$ & $1.1 \mathrm{E}-4$ & BCL2, BCL2L1, CASP3, PIK3CA, TP53, AKT1 \\
\end{tabular}

Table II. The 7 microRNAs most strongly targeting HNF1B, and their functions in cancer.

\begin{tabular}{|c|c|c|c|c|c|c|c|c|c|c|c|}
\hline \multirow{2}{*}{$\begin{array}{l}\text { MicroRNAs } \\
\text { (hsa-) }\end{array}$} & \multicolumn{9}{|c|}{10 microRNAs-mRNA interaction prediction tools } & \multirow{2}{*}{\multicolumn{2}{|c|}{$\begin{array}{l}\text { Drug resistance and related } \\
\text { functions in cancer (refs.) }\end{array}$}} \\
\hline & A & B & $\mathrm{C}$ & $\mathrm{D}$ & $\mathrm{E}$ & $\mathrm{F}$ & G & $\mathrm{H}$ & I & & \\
\hline miR-24 & 1 & 1 & 1 & 1 & 1 & 1 & 1 & 1 & 1 & 1 & Drug resistance-related (76-78) \\
\hline $\operatorname{miR}-32$ & 1 & 1 & 1 & 1 & 1 & 1 & 1 & 0 & 0 & 1 & $\begin{array}{l}\text { Inhibit invasion (73); promote growth } \\
\text { and migration ( } 74)\end{array}$ \\
\hline $\operatorname{miR}-217$ & 1 & 1 & 0 & 1 & 1 & 1 & 1 & 0 & 1 & 1 & Suppress cell proliferation and migration (75) \\
\hline miR-194 & 1 & 1 & 1 & 1 & 1 & 1 & 1 & 0 & 0 & 1 & Drug resistance-related (79) \\
\hline $\operatorname{miR}-367$ & 1 & 1 & 1 & 1 & 1 & 0 & 1 & 0 & 1 & 1 & Drug resistance-related (70) \\
\hline miR-25 & 1 & 1 & 1 & 1 & 1 & 1 & 1 & 0 & 0 & 1 & Drug resistance-related (80) \\
\hline $\operatorname{miR}-375$ & 1 & 1 & 1 & 1 & 1 & 0 & 1 & 0 & 0 & 1 & Drug resistance-related $(71,72)$ \\
\hline
\end{tabular}

A, DIANAmT; B, miRanda; C, miRDB; D, miRWalk; E, RNAhybrid; F, PICTAR4; G, PICTAR5; H, PITA; I, RNA22; J, Targetscan. 1, predicted by the software; 0 , not predicted.

ovarian cancer and drug resistance were varied, while it could still be sub-grouped. As shown in Fig. 4, cell growth related biological processes (covered 5 processes including cell proliferation, cell growth, growth, cell division and regeneration), cell cycle-related (covered 4 processes including cell cycle, regulation of cell cycle, cell cycle arrest and $\mathrm{S}$ phase) and gene expression regulation-related (covered 4 processes including gene expression, gene silencing, RNA interference and reverse transcription) may be the main processes by which HNF1B performs its drug resistance-related functions in ovarian cancer.

Pathway enrichment analysis of the genes co-occurring with $H N F 1 B$ indicating that HNF1B is associated with drug resistance in ovarian cancer. A total of 36 genes (TP53, BCL2, JUN, INS, MYC, H3F3AP6, TCEAL1, MUC16, ERBB2, WT1, ABCC2, EGFR, SYCE1L, KLHL1, CDKN1A, AFP, CCND1, PTEN, BCL2L1, BRCA1, CDX2, TYMS, TOP2A, AKT1, MSLN, EPCAM, KRT20, FOXL2, CASP3, HIF1A, COL11A2, PARP1, YBX1, PIK3CA, ERBB3 and CDH1) which notably co-occurred with HNF1B, ovarian cancer and drug resistance, were annotated $(\mathrm{p}<0.01)$ based on the analysis by Coremine Medical online tool, and provided a strong potentiality that HNF1B would perform its drug resistance-related functions in ovarian cancer through the interactions with those genes. The pathway enrichment analysis of the 36 genes was performed by DAVID online database to enrich the potential pathways with which HNF1B may be involved in the regulation of drug resistance. As shown in Table I, in addition to the pathways in cancers, 4 pathways including ErbB signaling pathway, focal adhesion, apoptosis and p53 signaling pathway were enriched, suggesting that HNF1B may be associated with drug resistance through its regulation on the 4 pathways.

MicroRNA-mRNA interaction analysis indicating the association of $H N F 1 B$ with drug resistance in ovarian cancer. Among the transcriptional targets of HNF1B were 426 microRNAs as predicted through miRWalk, which is made up of ten miRNA-mRNA prediction tools. Seven microRNAs, i.e., those yielding the highest score for HNF1B, were selected for subsequent analysis (Table II). As shown in Table II, among the top 7 microRNAs, 5 of them, including miR-24, -194, -367, -25 and -375 that targeted HNF1B influenced drug resistance in ovarian and other types of cancers. For example, miR-367 is specifically involved in the drug resistance in paclitaxelsensitive ovarian cancer cells (70). Similarly, miR-375 is associated with drug resistance in ovarian (71) and cervical cancer (72). Although no study has reported the role of miR-32 and -217 in drug resistance, it is associated with drug resistance-related processes such as cell proliferation, invasion and migration (73-75). Collectively, among the 7 microRNAs most strongly targeting HNF1B, the majority were involved in drug resistance in ovarian and other types of cancers, suggesting that the gene also mediates drug resistance. 


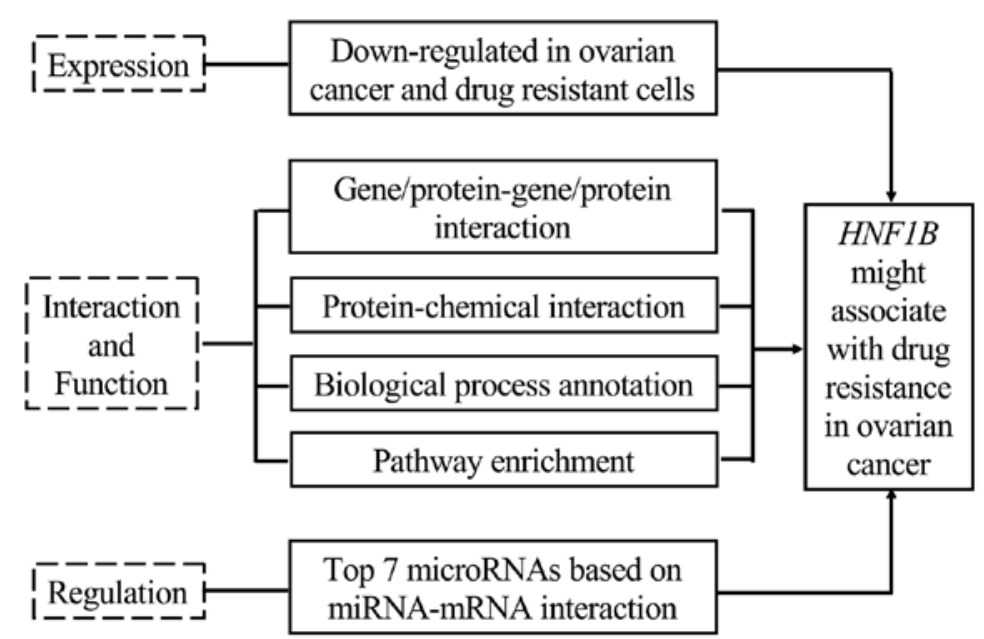

Figure 5. The overall procedure of bioinformatics analysis of HNF1B associated with drug resistance in ovarian cancer.

\section{Discussion}

The increasing number of sequenced genomes makes it important to develop methods that can assign functions to newly discovered genes in a timely and cost-effective manner. Experimental determination of protein functions is not only expensive but also time-consuming. Thus, computational approaches that utilize diverse biological datasets to generate automated predictions are useful, as they can guide laboratory experiments and facilitate more rapid annotation of genomes $(81,82)$. The computational approaches to gene function prediction have relied on a variety of genomic and proteomic data, at least including usage of microarray expression data (83), protein-protein interaction networks (84), protein-small molecule/chemical interactions (33-35), and the annotation of gene with biological processes (81). Thus, on the basis of many large-scale databases and networks, gene function prediction based on bioinformatics analysis is a potential, feasible and valuable way for gene function prediction (82). Using the comprehensive bioinformatics analyses, Yin et al (10) performed an integrated analysis of tumor suppressor genes with drug resistance in ovarian cancer, and two genes CCL21 and SPARCL1 associated with drug resistance were identified (85). Using similar bioinformatics analysis, upregulation of NEK2 was identified to be associated with drug resistance in ovarian cancer (86), and upregulation of E2F3 was identified to be associated with poor prognosis in HCC (87).

The association of HNF1B with drug resistance in ovarian and other cancers has yet to be reported. In the present study, a comprehensive bioinformatics analysis was performed to illustrate the associations of HNF1B with drug resistance in ovarian cancer, including array data retrieving, protein/ gene interaction, protein-small molecule/chemical interaction, biological process annotation, gene co-occurrence and pathway enrichment analysis, and microRNA-mRNA interaction. The database/tool/software used in this analysis including Oncomine online database $(27,28)$, GEO profiles $(28,29)$, GeneMANIA online tool (30-32), STITCH 4.0 beta (33-35), BiologicalNetworks2 (36,37), Coremine Medical (38), DAVID online tool $(39,40)$ and miRWalk $(41)$, which are all regularly used and reliable databases/tools. For example, GeneMANIA is a web-based database and a tool for prediction of gene functions on the basis of multiple networks derived from different genomic or proteomic data/sources (30). Seven organisms including Homo sapiens are currently supported, and hundreds of data sets have been collected from GEO, BioGRID, IRefIndex and I2D, as well as organism-specific functional genomics data sets (32). With a query gene, GeneMANIA could find a small set of genes that are most likely to share function with that gene based on their interactions with it, and with a query gene list, GeneMANIA could extend the list with functionally similar genes that it identifies using available genomics and proteomics data (32).

On the basis of comprehensive bioinformatics analyses (Fig. 5), we found that the mRNA expression of HNF1B in 586 ovarian cancer tissues and in drug-resistant cells is significantly decreased compared with their control counterparts, with 5.776- and 2.16-fold-changes, respectively. Protein/ gene interaction analysis indicated that among the total 20 proteins/genes that interacted with HNF1B, 14 of them were associated with drug resistance. Protein-small molecule/ chemical interactions analysis indicated that 4 of 6 chemicals that directly interacted with HNF1B were associated with drug resistance in ovarian cancer. MicroRNA-mRNA interaction analysis suggested that among the 7 microRNAs most strongly targeting HNF1B, the majority were involved in drug resistance in ovarian and other cancers. The biological process annotation indicated that a total of 24 biological processes were annotated with the HNF1B, ovarian cancer and drug resistance, and gene co-occurrence revealed that a total of 36 genes notably co-occurred with HNF1B, ovarian cancer and drug resistance. Collectively, given the strong interactions of HNF1B with proteins, genes, small molecules, microRNAs and biological processes, which were all associated with drug resistance in ovarian and other cancers, we concluded that the downregulation of HNF1B in ovarian serous cystadenocarcinomas and drug resistant ovarian cancer cells may potentially be involved in the development of drug resistance.

Several studies indicated that HNF1B is a downstream transcription activator of Wnt signaling pathway, and performs its functions via the interaction with the signaling (88-90). However, the pathway with which HNF1B is involved 
in cancer development is less understood. In the present study, pathway enrichment analysis of 36 genes which co-occurred with HNF1B, ovarian cancer and drug resistance, was performed. In addition to the pathways in cancer and pathways related to specified cancers (such as prostate and colorectal cancer), 4 pathways including ErbB signaling, focal adhesion, apoptosis and p53 signaling were enriched, suggesting that HNF1B may contribute to drug resistance in ovarian cancer via those pathways. ErbB signaling (91), focal adhesion $(92,93)$, apoptosis $(94,95)$ and p53 signaling $(96,97)$ have been reported to associate with drug resistance in ovarian cancer. For example, miR-21 regulates drug resistance via apoptosis and cellular survival pathways (94), and loss of DOK2 induces carboplatin resistance in ovarian cancer via suppression of apoptosis (98).

In summary, on the basis of comprehensive bioinformatics analysis, for the first time, we illustrated that the downregulation of HNF1B may be associated with drug resistance in ovarian cancer. The present study may set the stage for further investigation of the drug resistance-related functions of HNF1B in ovarian cancer.

\section{Acknowledgements}

This study was sponsored by the Shandong Province Science and Technology Development Program (2012GSF11821).

\section{References}

1. Siegel R, Naishadham D and Jemal A: Cancer statistics, 2012. CA Cancer J Clin 62: 10-29, 2012.

2. Vaughan S, Coward JI, Bast RC Jr, Berchuck A, Berek JS, BrentonJD, Coukos G,Crum CC,DrapkinR,EtemadmoghadamD, Friedlander M, Gabra H, Kaye SB, Lord CJ, Lengyel E, Levine DA, McNeish IA, Menon U, Mills GB, Nephew KP, Oza AM, Sood AK, Stronach EA, Walczak H, Bowtell DD and Balkwill FR: Rethinking ovarian cancer: recommendations for improving outcomes. Nat Rev Cancer 11: 719-725, 2011.

3. Jemal A, Siegel R, Ward E, Hao Y, Xu J, Murray T and Thun MJ: Cancer statistics, 2008. CA Cancer J Clin 58: 71-96, 2008.

4. Sorrentino A, Liu CG, Addario A, Peschle C, Scambia G and Ferlini C: Role of microRNAs in drug-resistant ovarian cancer cells. Gynecol Oncol 111: 478-486, 2008.

5. Cannistra SA: Cancer of the ovary. N Engl J Med 351: 2519-2529, 2004.

6. Gottesman MM: Mechanisms of cancer drug resistance. Annu Rev Med 53: 615-627, 2002.

7. Johnson SW, Ozols RF and Hamilton TC: Mechanisms of drug resistance in ovarian cancer. Cancer 71 (Suppl 2): S644-S649, 1993.

8. Cheng JQ, Jiang X, Fraser M, Li M, Dan HC, Sun M and Tsang BK: Role of X-linked inhibitor of apoptosis protein in chemoresistance in ovarian cancer: possible involvement of the phosphoinositide-3 kinase/Akt pathway. Drug Resist Updat 5: 131-146, 2002.

9. Fraser M, Leung BM, Yan X, Dan HC, Cheng JQ and Tsang BK: p53 is a determinant of X-linked inhibitor of apoptosis protein/ Akt-mediated chemoresistance in human ovarian cancer cells. Cancer Res 63: 7081-7088, 2003.

10. Yin F, Liu X, Li D, Wang Q, Zhang W and Li L: Tumor suppressor genes associated with drug resistance in ovarian cancer (Review). Oncol Rep 30: 3-10, 2013.

11. Bach I and Yaniv M: More potent transcriptional activators or a transdominant inhibitor of the HNF1 homeoprotein family are generated by alternative RNA processing. EMBO J 12: 4229-4242, 1993 .

12. Edghill EL, Bingham C, Slingerland AS, Minton JA, Noordam C, Ellard S and Hattersley AT: Hepatocyte nuclear factor-1 beta mutations cause neonatal diabetes and intrauterine growth retardation: support for a critical role of HNF-1 $\beta$ in human pancreatic development. Diabet Med 23: 1301-1306, 2006.
13. Wu G, Bohn S and Ryffel GU: The HNF1 $\beta$ transcription factor has several domains involved in nephrogenesis and partially rescues Pax8/lim1-induced kidney malformations. Eur J Biochem 271: 3715-3728, 2004.

14. Shao DD, Tsherniak A, Gopal S, Weir BA, Tamayo P, Stransky N, Schumacher SE, Zack TI, Beroukhim R, Garraway LA, Margolin AA, Root DE, Hahn WC and Mesirov JP: ATARiS: computational quantification of gene suppression phenotypes from multisample RNAi screens. Genome Res 23: 665-678, 2013.

15. Rebouissou S, Vasiliu V, Thomas C, Bellanné-Chantelot C, Bui H, Chrétien Y, Timsit J, Rosty C, Laurent-Puig P, Chauveau D and Zucman-Rossi J: Germline hepatocyte nuclear factor $1 \alpha$ and $1 \beta$ mutations in renal cell carcinomas. Hum Mol Genet 14: 603-614, 2005.

16. Terasawa K, Toyota M, Sagae S, Ogi K, Suzuki H, Sonoda T, Akino K, Maruyama R, Nishikawa N, Imai K, Shinomura Y, Saito T and Tokino T: Epigenetic inactivation of TCF2 in ovarian cancer and various cancer cell lines. Br J Cancer 94: 914-921, 2006.

17. Silva TD, Vidigal VM, Felipe AV, DE Lima JM, Neto RA, Saad SS and Forones NM: DNA methylation as an epigenetic biomarker in colorectal cancer. Oncol Lett 6: 1687-1692, 2013.

18. Grisanzio C, Werner L, Takeda D, Awoyemi BC, Pomerantz MM, Yamada H, Sooriakumaran $\mathrm{P}$, Robinson BD, Leung R, Schinzel AC, Mills I, Ross-Adams H, Neal DE, Kido M, Yamamoto T, Petrozziello G, Stack EC, Lis R, Kantoff PW, Loda M, Sartor O, Egawa S, Tewari AK, Hahn WC and Freedman ML: Genetic and functional analyses implicate the NUDT11, HNF1B, and SLC22A3 genes in prostate cancer pathogenesis. Proc Natl Acad Sci USA 109: 11252-11257, 2012.

19. Gudmundsson J, Sulem P, Steinthorsdottir V, Bergthorsson JT, Thorleifsson G, Manolescu A, Rafnar T, Gudbjartsson D, Agnarsson BA, Baker A, Sigurdsson A, Benediktsdottir KR, Jakobsdottir M, Blondal T, Stacey SN, Helgason A, Gunnarsdottir S, Olafsdottir A, Kristinsson KT, Birgisdottir B, Ghosh S, Thorlacius S, Magnusdottir D, Stefansdottir G, Kristjansson K, Bagger Y, Wilensky RL, Reilly MP, Morris AD, Kimber CH, Adeyemo A, Chen Y, Zhou J, So WY, Tong PC, Ng MC, Hansen T, Andersen G, Borch-Johnsen K, Jorgensen T, Tres A, Fuertes F, Ruiz-Echarri M, Asin L, Saez B, van Boven E, Klaver S, Swinkels DW, Aben KK, Graif T, Cashy J, Suarez BK, van Vierssen Trip O, Frigge ML, Ober C, Hofker MH, Wijmenga C, Christiansen C, Rader DJ, Palmer CN, Rotimi C, Chan JC, Pedersen O, Sigurdsson G, Benediktsson R, Jonsson E, Einarsson GV, Mayordomo JI, Catalona WJ, Kiemeney LA, Barkardottir RB, Gulcher JR, Thorsteinsdottir U, Kong A and Stefansson K: Two variants on chromosome 17 confer prostate cancer risk, and the one in $T C F 2$ protects against type 2 diabetes. Nat Genet 39: 977-983, 2007.

20. Sun J, Zheng SL, Wiklund F, Isaacs SD, Purcell LD, Gao Z, Hsu FC, Kim ST, Liu W, Zhu Y, Stattin P, Adami HO, Wiley KE, Dimitrov L, Li T, Turner AR, Adams TS, Adolfsson J, Johansson JE, Lowey J, Trock BJ, Partin AW, Walsh PC, Trent JM, Duggan D, Carpten J, Chang BL, Grönberg H, Isaacs $\mathrm{WB}$ and $\mathrm{Xu} \mathrm{J}$ : Evidence for two independent prostate cancer risk-associated loci in the $H N F 1 B$ gene at $17 \mathrm{q} 12$. Nat Genet 40: 1153-1155, 2008.

21. Thomas G, Jacobs KB, Yeager M, Kraft P, Wacholder S, Orr N, Yu K, Chatterjee N, Welch R, Hutchinson A, Crenshaw A, Cancel-Tassin G, Staats BJ, Wang Z, Gonzalez-Bosquet J, Fang J, Deng X, Berndt SI, Calle EE, Feigelson HS, Thun MJ, Rodriguez C, Albanes D, Virtamo J, Weinstein S, Schumacher FR, Giovannucci E, Willett WC, Cussenot O, Valeri A, Andriole GL, Crawford ED, Tucker M, Gerhard DS, Fraumeni JF Jr, Hoover R, Hayes RB, Hunter DJ and Chanock SJ: Multiple loci identified in a genome-wide association study of prostate cancer. Nat Genet 40: 310-315, 2008.

22. Spurdle AB1, Thompson DJ, Ahmed S, Ferguson K, Healey CS, O'Mara T, Walker LC, Montgomery SB, Dermitzakis ET; Australian National Endometrial Cancer Study Group, Fahey P, Montgomery GW, Webb PM, Fasching PA, Beckmann MW, Ekici AB, Hein A, Lambrechts D, Coenegrachts L, Vergote I, Amant F, Salvesen HB, Trovik J, Njolstad TS, Helland H, Scott RJ, Ashton K, Proietto T, Otton G; National Study of Endometrial Cancer Genetics Group, Tomlinson I, Gorman M, Howarth K, Hodgson S, Garcia-Closas M, Wentzensen N, Yang H, Chanock S, Hall P, Czene K, Liu J, Li J, Shu XO, Zheng W, Long J, Xiang YB, Shah M, Morrison J, Michailidou K, Pharoah PD, Dunning AM and Easton DF: Genome-wide association study identifies a common variant associated with risk of endometrial cancer. Nat Genet 43: 451-454, 2011 
23. Elliott KS, Zeggini E, McCarthy MI, Gudmundsson J, Sulem P, Stacey SN, Thorlacius S, Amundadottir L, Gronberg H, Xu J, Gaborieau V, Eeles RA, Neal DE, Donovan JL, Hamdy FC, Muir K, Hwang SJ, Spitz MR, Zanke B, Carvajal-Carmona L, Brown KM, Hayward NK, Macgregor S, Tomlinson IP, Lemire M, Amos CI, Murabito JM, Isaacs WB, Easton DF, Brennan P, Barkardottir RB, Gudbjartsson DF, Rafnar T, Hunter DJ, Chanock SJ, Stefansson K and Ioannidis JP: Evaluation of association of $H N F 1 B$ variants with diverse cancers: collaborative analysis of data from 19 genome-wide association studies. PLoS One 5: e10858, 2010.

24. Shen H, Fridley BL, Song H, Lawrenson K, Cunningham JM, Ramus SJ, Cicek MS, Tyrer J, Stram D, Larson MC, Köbel M; PRACTICAL Consortium, Ziogas A, Zheng W, Yang HP, Wu AH, Wozniak EL, Woo YL, Winterhoff B, Wik E, Whittemore AS Wentzensen N, Weber RP, Vitonis AF, Vincent D, Vierkant RA, Vergote I, Van Den Berg D, Van Altena AM, Tworoger SS, Thompson PJ, Tessier DC, Terry KL, Teo SH, Templeman C, Stram DO, Southey MC, Sieh W, Siddiqui N, Shvetsov YB, Shu XO, Shridhar V, Wang-Gohrke S, Severi G, Schwaab I, Salvesen HB, Rzepecka IK, Runnebaum IB, Rossing MA, Rodriguez-Rodriguez L, Risch HA, Renner SP, Poole EM, Pike MC, Phelan CM, Pelttari LM, Pejovic T, Paul J, Orlow I, Omar SZ, Olson SH, Odunsi K, Nickels S, Nevanlinna H, Ness RB, Narod SA, Nakanishi T, Moysich KB, Monteiro AN Moes-Sosnowska J, Modugno F, Menon U, McLaughlin JR, McGuire V, Matsuo K, Adenan NA, Massuger LF, Lurie G, Lundvall L, Lubiński J, Lissowska J, Levine DA, Leminen A, Lee AW, Le ND, Lambrechts S, Lambrechts D, Kupryjanczyk J, Krakstad C, Konecny GE, Kjaer SK, Kiemeney LA, Kelemen LE, Keeney GL, Karlan BY, Karevan R, Kalli KR, Kajiyama H, Ji BT, Jensen A, Jakubowska A, Iversen E, Hosono S, Høgdall CK, Høgdall E, Hoatlin M, Hillemanns P, Heitz F, Hein R, Harter P, Halle MK, Hall P, Gronwald J, Gore M, Goodman MT, Giles GG, Gentry-Maharaj A, Garcia-Closas M, Flanagan JM, Fasching PA, Ekici AB, Edwards R, Eccles D, Easton DF, Dürst M, du Bois A, Dörk T, Doherty JA, Despierre E, Dansonka-Mieszkowska A, Cybulski C, Cramer DW, Cook LS Chen X, Charbonneau B, Chang-Claude J, Campbell I, Butzow R, Bunker CH, Brueggmann D, Brown R, Brooks-Wilson A, Brinton LA, Bogdanova N, Block MS, Benjamin E, Beesley J, Beckmann MW, Bandera EV, Baglietto L, Bacot F, Armasu SM, K, Hildebrandt MA; Australian Ovarian Cancer Study Group; Australian Cancer Study, Schildkraut JM Sellers TA, Huntsman D, Berchuck A, Chenevix-Trench G, Gayther SA, Pharoah PD, Laird PW, Goode EL and Pearce CL: Epigenetic analysis leads to identification of $H N F 1 B$ as a subtypespecific susceptibility gene for ovarian cancer. Nat Commun 4: 1628,2013

25. Anglesio MS, Wiegand KC, Melnyk N, Chow C, Salamanca C, Prentice LM, Senz J, Yang W, Spillman MA, Cochrane DR, Shumansky K, Shah SP, Kalloger SE and Huntsman DG: Type-specific cell line models for type-specific ovarian cancer research. PLoS One 8: e72162, 2013.

26. Kalloger SE, Köbel M, Leung S, Mehl E, Gao D, Marcon KM, Chow C, Clarke BA, Huntsman DG and Gilks CB: Calculator for ovarian carcinoma subtype prediction. Mod Pathol 24: 512-521, 2011.

27. Rhodes DR, Yu J, Shanker K, Deshpande N, Varambally R, Ghosh D, Barrette T, Pandey A and Chinnaiyan AM: ONCOMINE: a cancer microarray database and integrated datamining platform. Neoplasia 6: 1-6, 2004.

28. Edgar R, Domrachev M and Lash AE: Gene Expression Omnibus: NCBI gene expression and hybridization array data repository. Nucleic Acids Res 30: 207-210, 2002.

29. Barrett $T$ and Edgar R: Mining microarray data at NCBI's Gene Expression Omnibus (GEO)*. Methods Mol Biol 338: 175-190, 2006.

30. Mostafavi S, Ray D, Warde-Farley D, Grouios C and Morris Q: GeneMANIA: a real-time multiple association network integration algorithm for predicting gene function. Genome Biol 9 (Suppl 1): S4, 2008.

31. Warde-Farley D, Donaldson SL, Comes O, Zuberi K, Badrawi R, Chao P, Franz M, Grouios C, Kazi F, Lopes CT, Maitland A, Mostafavi S, Montojo J, Shao Q, Wright G, Bader GD and Morris Q: The GeneMANIA prediction server: biological network integration for gene prioritization and predicting gene function. Nucleic Acids Res 38: W214-W220, 2010.

32. Zuberi K, Franz M, Rodriguez H, Montojo J, Lopes CT, Bader GD and Morris Q: GeneMANIA prediction server 2013 update. Nucleic Acids Res 41: W115-W122, 2013.
33. Kuhn M, Szklarczyk D, Franceschini A, von Mering C, Jensen LJ and Bork P: STITCH 3: zooming in on protein-chemical interactions. Nucleic Acids Res 40: D876-D880, 2012.

34. Kuhn M, Szklarczyk D, Franceschini A, Campillos M, von Mering C, Jensen LJ, Beyer A and Bork P: STITCH 2: an interaction network database for small molecules and proteins. Nucleic Acids Res 38: D552-D556, 2010.

35. Kuhn M, von Mering C, Campillos M, Jensen LJ and Bork P: STITCH: interaction networks of chemicals and proteins. Nucleic Acids Res 36: D684-D688, 2008.

36. Baitaluk M, Sedova M, Ray A and Gupta A: BiologicalNetworks: visualization and analysis tool for systems biology. Nucleic Acids Res 34: W466-W471, 2006.

37. Kozhenkov S, Dubinina Y, Sedova M, Gupta A, Ponomarenko J and Baitaluk M: BiologicalNetworks 2.0 - an integrative view of genome biology data. BMC Bioinformatics 11: 610, 2010.

38. de Leeuw N1, Dijkhuizen T, Hehir-Kwa JY, Carter NP, Feuk L, Firth HV, Kuhn RM, Ledbetter DH, Martin CL, van Ravenswaaij-Arts CM, Scherer SW, Shams S, Van Vooren S, Sijmons R, Swertz M and Hastings R: Diagnostic interpretation of array data using public databases and internet sources. Hum Mutat 33: 930-940, 2012.

39. Huang da W, Sherman BT and Lempicki RA: Systematic and integrative analysis of large gene lists using DAVID bioinformatics resources. Nat Protoc 4: 44-57, 2008.

40. Huang da W, Sherman BT and Lempicki RA: Bioinformatics enrichment tools: paths toward the comprehensive functional analysis of large gene lists. Nucleic Acids Res 37: 1-13, 2009.

41. Dweep H, Sticht C, Pandey P and Gretz N: miRWalk - database: prediction of possible miRNA binding sites by 'walking' the genes of three genomes. J Biomed Inform 44: 839-847, 2011.

42. Zhou C, Smith JL and Liu J: Role of BRCA1 in cellular resistance to paclitaxel and ionizing radiation in an ovarian cancer cell line carrying a defective BRCA1. Oncogene 22: 2396-2404, 2003.

43. Yang D, Khan S, Sun Y, Hess K, Shmulevich I, Sood AK and Zhang W: Association of BRCA1 and BRCA2 mutations with survival, chemotherapy sensitivity, and gene mutator phenotype in patients with ovarian cancer. JAMA 306: 1557-1565, 2011.

44. Lee S, Choi EJ, Jin C and Kim DH: Activation of PI3K/Akt pathway by PTEN reduction and PIK3CA mRNA amplification contributes to cisplatin resistance in an ovarian cancer cell line. Gynecol Oncol 97: 26-34, 2005.

45. Wu H, Cao Y, Weng D, Xing H, Song X, Zhou J, Xu G, Lu Y, Wang S and Ma D: Effect of tumor suppressor gene PTEN on the resistance to cisplatin in human ovarian cancer cell lines and related mechanisms. Cancer Lett 271: 260-271, 2008.

46. Yang G, Xiao X, Rosen DG, Cheng X, Wu X, Chang B, Liu G, Xue F, Mercado-Uribe I, Chiao P, Du X and Liu J: The biphasic role of NF- $\kappa \mathrm{B}$ in progression and chemoresistance of ovarian cancer. Clin Cancer Res 17: 2181-2194, 2011.

47. Zhang X, Wang X, Song X, Liu C, Shi Y, Wang Y, Afonja O, $\mathrm{MaC}$, Chen YH and Zhang L: Programmed cell death 4 enhances chemosensitivity of ovarian cancer cells by activating death receptor pathway in vitro and in vivo. Cancer Sci 101: 2163-2170, 2010.

48. Strathdee G, MacKean MJ, Illand M and Brown R: A role for methylation of the $h M L H 1$ promoter in loss of hMLH1 expression and drug resistance in ovarian cancer. Oncogene 18: 2335-2341, 1999.

49. Plumb JA, Strathdee G, Sludden J, Kaye SB and Brown R: Reversal of drug resistance in human tumor xenografts by 2'-deoxy-5-azacytidine-induced demethylation of the $h M L H 1$ gene promoter. Cancer Res 60: 6039-6044, 2000.

50. Qiu L, Di W, Jiang Q, Scheffler E, Derby S, Yang J, Kouttab N, Wanebo H, Yan B and Wan Y: Targeted inhibition of transient activation of the EGFR-mediated cell survival pathway enhances paclitaxel-induced ovarian cancer cell death. Int J Oncol 27: 1441-1448, 2005.

51. Skirnisdóttir I, Sorbe B and Seidal T: The growth factor receptors HER-2/neu and EGFR, their relationship, and their effects on the prognosis in early stage (FIGO I-II) epithelial ovarian carcinoma. Int J Gynecol Cancer 11: 119-129, 2001.

52. Houvras Y, Benezra M, Zhang H, Manfredi JJ, Weber BL and Licht JD: BRCA1 physically and functionally interacts with ATF1. J Biol Chem 275: 36230-36237, 2000.

53. Balch C, Naegeli K, Nam S, Ballard B, Hyslop A, Melki C, Reilly E, Hur MW and Nephew KP: A unique histone deacetylase inhibitor alters microRNA expression and signal transduction in chemoresistant ovarian cancer cells. Cancer Biol Ther 13: 681-693, 2012. 
54. Belanger AS, Tojcic J, Harvey M and Guillemette C: Regulation of UGT1A1 and HNF1 transcription factor gene expression by DNA methylation in colon cancer cells. BMC Mol Biol 11: 9, 2010.

55. Reuning U, Guerrini L, Nishiguchi T, Page S, Seibold H, Magdolen V, Graeff $\mathrm{H}$ and Schmitt M: Rel transcription factors contribute to elevated urokinase expression in human ovarian carcinoma cells. Eur J Biochem 259: 143-148, 1999.

56. Chen H, Hao J, Wang L and Li Y: Coexpression of invasive markers (uPA, CD44) and multiple drug-resistance proteins (MDR1, MRP2) is correlated with epithelial ovarian cancer progression. Br J Cancer 101: 432-440, 2009.

57. Danoy P, Sonoda E, Lathrop M, Takeda S and Matsuda F: A naturally occurring genetic variant of human XRCC2 $(\mathrm{R} 188 \mathrm{H})$ confers increased resistance to cisplatin-induced DNA damage. Biochem Biophys Res Commun 352: 763-768, 2007.

58. Fink D, Nebel S, Aebi S, Nehme A and Howell S: Loss of DNA mismatch repair due to knockout of MSH2 or PMS2 results in resistance to cisplatin and carboplatin. Int J Oncol 11: 539-542, 1997.

59. Gerhardt J, Montani M, Wild P, Beer M, Huber F, Hermanns T, Muntener M and Kristiansen G: FOXA1 promotes tumor progression in prostate cancer and represents a novel hallmark of castration-resistant prostate cancer. Am J Pathol 180: 848-861, 2012.

60. Nadkarni A, Furda A, Rajesh C, McInnes C, Ruch RJ and Pittman DL: Functional characterization of the RAD51D E233G genetic variant. Pharmacogenet Genomics 19: 153-160, 2009.

61. Oh SJ, Han HK, Kang KW, Lee YJ and Lee MY: Menadione serves as a substrate for P-glycoprotein: implication in chemosensitizing activity. Arch Pharm Res 36: 509-516, 2013.

62. Gilloteaux J, Jamison JM, Lorimer HE, Jarjoura D, Taper HS Calderon PB, Neal DR and Summers JL: Autoschizis: a new form of cell death for human ovarian carcinoma cells following ascorbate:menadione treatment. Nuclear and DNA degradation. Tissue Cell 36: 197-209, 2004.

63. Gilloteaux J, Jamison JM, Arnold D, Jarjoura D, Von Greuningen V and Summers JL: Autoschizis of human ovarian carcinoma cells: scanning electron and light microscopy of a new cell death induced by sodium ascorbate: menadione treatment. Scanning 25 : 137-149, 2003

64. Zhang D, Holmes WF, Wu S, Soprano DR and Soprano KJ: Retinoids and ovarian cancer. J Cell Physiol 185: 1-20, 2000

65. Pratt MA, Niu MY and Renart LI: Regulation of survivin by retinoic acid and its role in paclitaxel-mediated cytotoxicity in MCF-7 breast cancer cells. Apoptosis 11: 589-605, 2006.

66. Zhang Y, Guan DX, Shi J, Gao H, Li JJ, Zhao JS, Qiu L, Liu J Li N, Guo WX, Xue J, Zhou FG, Wu MC, Wang HY, Xie D and Cheng SQ: All-trans retinoic acid potentiates the chemotherapeutic effect of cisplatin by inducing differentiation of tumor initiating cells in liver cancer. J Hepatol 59: 1255-1263, 2013.

67. Lu M, Xiao L and Li Z: The relationship between p38MAPK and apoptosis during paclitaxel resistance of ovarian cancer cells. J Huazhong Univ Sci Technolog Med Sci 27: 725-728, 2007.

68. Lee LF, Haskill JS, Mukaida N, Matsushima K and Ting JP. Identification of tumor-specific paclitaxel (Taxol)-responsive regulatory elements in the interleukin- 8 promoter. Mol Cell Biol 17: 5097-5105, 1997.

69. Duan Z, Feller AJ, Penson RT, Chabner BA and Seiden MV: Discovery of differentially expressed genes associated with paclitaxel resistance using cDNA array technology: analysis of interleukin (IL) 6, IL-8, and monocyte chemotactic protein 1 in the paclitaxel-resistant phenotype. Clin Cancer Res 5: 3445-3453, 1999.

70. Chen N, Chon HS, Xiong Y, Marchion DC, Judson PL, Hakam A, Gonzalez-Bosquet J, Permuth-Wey J, Wenham RM, Apte SM, Cheng JQ, Sellers TA and Lancaster JM: Human cancer cell line microRNAs associated with in vitro sensitivity to paclitaxel. Oncol Rep 31: 376-383, 2014

71. Shao X, Mei W, Weng W, Qin J, Zhou J, Liu J and Cheng J: Mir-375 enhances ruthenium-derived compound Rawq01 induced cell death in human ovarian cancer. Int J Clin Exp Pathol 6: 1095-1102, 2013.

72. Shen Y, Wang P, Li Y, Ye F, Wang F, Wan X, Cheng X, Lu W and $\mathrm{Xie} \mathrm{X}$ : miR-375 is upregulated in acquired paclitaxel resistance in cervical cancer. Br J Cancer 109: 92-99, 2013

73. Zhang J, Kuai X, Song M, Chen X, Yu Z, Zhang H and Mao Z: microRNA-32 inhibits the proliferation and invasion of the SGC-7901 gastric cancer cell line in vitro. Oncol Lett 7: 270-274, 2014.
74. Wu W, Yang J, Feng X, Wang H, Ye S, Yang P, Tan W, Wei G and Zhou Y: MicroRNA-32 (miR-32) regulates phosphatase and tensin homologue (PTEN) expression and promotes growth migration, and invasion in colorectal carcinoma cells. Mol Cancer 12: 30, 2013.

75. Li H, Zhao J, Zhang JW, Huang QY, Huang JZ, Chi LS, Tang HJ, Liu GQ, Zhu DJ and Ma WM: MicroRNA-217, down-regulated in clear cell renal cell carcinoma and associated with lower survival, suppresses cell proliferation and migration. Neoplasma 60: 511-515, 2013.

76. Husted S, Søkilde R, Rask L, Cirera S, Busk PK, Eriksen J and Litman T: MicroRNA expression profiles associated with development of drug resistance in Ehrlich ascites tumor cells. Mol Pharm 8: 2055-2062, 2011.

77. Singh R and Saini N: Downregulation of BCL2 by miRNAs augments drug-induced apoptosis - a combined computational and experimental approach. J Cell Sci 125: 1568-1578, 2012.

78. Srivastava N, Manvati S, Srivastava A, Pal R, Kalaiarasan P, Chattopadhyay S, Gochhait S, Dua R and Bamezai RN: miR-24-2 controls $H 2 A F X$ expression regardless of gene copy number alteration and induces apoptosis by targeting antiapoptotic gene $B C L-2$ : a potential for therapeutic intervention. Breast Cancer Res 13: R39, 2011

79. Dong P, Kaneuchi M, Watari H, Hamada J, Sudo S, Ju J and Sakuragi N: MicroRNA-194 inhibits epithelial to mesenchymal transition of endometrial cancer cells by targeting oncogene BMI-1. Mol Cancer 10: 99, 2011.

80. Zhou Y, Hu Y, Yang M, Jat P, Li K, Lombardo Y, Xiong D, Coombes RC, Raguz S and Yagüe E: The miR-106b 25 cluster promotes bypass of doxorubicin-induced senescence and increase in motility and invasion by targeting the E-cadherin transcriptional activator EP300. Cell Death Differ 21: 462-474, 2014.

81. Phuong $\mathrm{T}$ and Nhung N: Predicting gene function using similarity learning. BMC Genomics 14 (Suppl 4): S4, 2013

82. Sharan R, Ulitsky I and Shamir R: Network-based prediction of protein function. Mol Syst Biol 3: 88, 2007.

83. Stuart JM, Segal E, Koller D and Kim SK: A gene-coexpression network for global discovery of conserved genetic modules. Science 302: 249-255, 2003.

84. Uetz P, Giot L, Cagney G, Mansfield TA, Judson RS, Knight JR, Lockshon D, Narayan V, Srinivasan M, PochartP, Qureshi-Emili A, Li Y, Godwin B, Conover D, Kalbfleisch T, Vijayadamodar G, Yang M, Johnston M, Fields S and Rothberg JM: A comprehensive analysis of protein-protein interactions in Saccharomyces cerevisiae. Nature 403: 623-627, 2000.

85. Yin F, Liu X, Li D, Wang Q, Zhang W and Li L: Bioinformatic analysis of chemokine (C-C motif) ligand 21 and SPARC-like protein 1 revealing their associations with drug resistance in ovarian cancer. Int J Oncol 42: 1305-1316, 2013.

86. Liu X, Gao Y, Lu Y, Zhang J, Li L and Yin F: Upregulation of NEK2 is associated with drug resistance in ovarian cancer. Oncol Rep 31: 745-754, 2014

87. Zeng X, Yin F, Liu X, Xu J, Xu Y, Huang J, Nan Y and Qiu X: Upregulation of E2F transcription factor 3 is associated with poor prognosis in hepatocellular carcinoma. Oncol Rep 31: 1139-1146, 2014.

88. Roose $\mathrm{J}$ and Clevers $\mathrm{H}$ : TCF transcription factors: molecular switches in carcinogenesis. Biochim Biophys Acta 1424: M23-M37, 1999.

89. Lancman JJ, Zvenigorodsky N, Gates KP, Zhang D, Solomon K, Humphrey RK, Kuo T, Setiawan L, Verkade H, Chi YI, Jhala US, Wright CV, Stainier DY and Dong PD: Specification of hepatopancreas progenitors in zebrafish by hnflba and wnt $2 b b$. Development 140: 2669-2679, 2013.

90. Welters HJ, Oknianska A, Erdmann KS, Ryffel GU and Morgan NG: The protein tyrosine phosphatase-BL, modulates pancreatic $\beta$-cell proliferation by interaction with the Wnt signalling pathway. J Endocrinol 197: 543-552, 2008.

91. Manandhar S, Choi BH, Jung KA, Ryoo IG, Song M, Kang SJ, Choi HG, Kim JA, Park PH and Kwak MK: NRF2 inhibition represses ErbB2 signaling in ovarian carcinoma cells: implications for tumor growth retardation and docetaxel sensitivity. Free Radic Biol Med 52: 1773-1785, 2012

92. Kang $\mathrm{Y}, \mathrm{Hu} \mathrm{W}$, Ivan $\mathrm{C}$, Dalton $\mathrm{HJ}$, Miyake T, Pecot CV, Zand B, Liu T, Huang J, Jennings NB, Rupaimoole R, Taylor M, Pradeep S, Wu SY, Lu C, Wen Y, Liu J and Sood AK: Role of focal adhesion kinase in regulating YB-1-mediated paclitaxel resistance in ovarian cancer. J Natl Cancer Inst 105: 1485-1495, 2013. 
93. Halder J, Landen CN Jr, Lutgendorf SK, Li Y, Jennings NB, Fan D, Nelkin GM, Schmandt R, Schaller MD and Sood AK: Focal adhesion kinase silencing augments docetaxel-mediated apoptosis in ovarian cancer cells. Clin Cancer Res 11: 8829-8836, 2005.

94. Chan JK, Blansit K, Kiet T, Sherman A, Wong G, Earle C and Bourguignon LY: The inhibition of $m i R-21$ promotes apoptosis and chemosensitivity in ovarian cancer. Gynecol Oncol 132: 739-744, 2014.

95. Farrand L, Byun S, Kim JY, Im-Aram A, Lee J, Lim S, Lee KW, Suh JY, Lee HJ and Tsang BK: Piceatannol enhances cisplatin sensitivity in ovarian cancer via modulation of $\mathrm{p} 53$, X-linked inhibitor of apoptosis protein (XIAP), and mitochondrial fission. J Biol Chem 288: 23740-23750, 2013.
96. Benoit DS, Henry SM, Shubin AD, Hoffman AS and Stayton PS: $\mathrm{pH}$-responsive polymeric sirna carriers sensitize multidrug resistant ovarian cancer cells to doxorubicin via knockdown of polo-like kinase 1. Mol Pharm 7: 442-455, 2010.

97. Yan X, Fraser M, Qiu Q and Tsang BK: Over-expression of PTEN sensitizes human ovarian cancer cells to cisplatin-induced apoptosis in a p53-dependent manner. Gynecol Oncol 102: 348-355, 2006

98. Lum E, Vigliotti M, Banerjee N, Cutter N, Wrzeszczynski KO, Khan S, Kamalakaran S, Levine DA, Dimitrova N and Lucito R: Loss of $D O K 2$ induces carboplatin resistance in ovarian cancer via suppression of apoptosis. Gynecol Oncol 130: 369-376, 2013. 